\title{
KONTRIBUSI HUKUM ISLAM DALAM PROSES TAQNÎN UNDANG-UNDANG NOMOR 10 TAHUN 1998 TENTANG PERBANKAN
}

\author{
Abdul Hamid \\ Fakultas Syariah dan Hukum UIN Sunan Gunung Djati Bandung \\ E-mail: abd_hamid@uinsgd.ac.id
}

\begin{abstract}
The existence of Islamic Law Banking in Indonesia has been recognized and known from the Banking Law Number 7 of 1992. This continued with the Banking Law Number 10 of 1998 Juncto Number 7 of 1992, and it is finally regulated with the Banking Law Number 21 of 2008 which confirms that Islamic banking is part of the national banking system. This paper will explain the transformation process of Islamic law into Sharia banking rule in Indonesia. As described in some literatures that Shariah Bank is one of the financial Islamic instruments and institutions. So, I can say that the existence of Shariah bank is the representation of the principles of Islamic economics in fiqh muamalah and the implementation of the Islamic economics norms which can help to improve the economic performance in Indonesia.
\end{abstract}

\begin{abstract}
Abstrak
Diberlakukannya UU No. 7 Tahun 1992 tentang Perbankan, keberadaan bank syariah dalam sistem perbankan di Indonesia telah diakui dan dikenal. Hal ini berlanjut dengan dengan diberlakukannya UU No. 10 Tahun 1998 jo. UU No. 7 Tahun 1992 tentang Perbankan, yang pada akhirnya juga dibentuk aturan tersendiri dengan berlakunya UU No. 21 Tahun 2008 tentang Perbankan Syariah yang mempertegas bahwa perbankan syariah adalah bagian dari sistem perbankan nasional. Tulisan ini akan menjelaskan proses transformasi hukum Islam dan proses taqnîn undang-undang perbankan syari'ah di Indonesia. Sebagaimana dijelaskan dalam beberapa literatur bahwa bank syari'ah merupakan salah satu instrumen lembaga keuangan syari'ah. Eksistensi bank syari'ah merupakan representasi dari prinsip-prinsip ekonomi Islam dalam fikih muamalah dan implementasi dari kaidah-kaidah hukum ekonomi Islam yang dapat membantu dalam meningkatkan kemampuan ekonomi di Indonesia.
\end{abstract}

Kata Kunci:

Hukum Islam, Taqnîn, Undang-Undang, Perbankan

\section{A. Pendahuluan}

Sejak diberlakukannya UU No. 7 Tahun 1992 tentang Perbankan, keberadaan bank syariah dalam sistem perbankan di Indonesia sebenarnya telah diakui dan dikenal. Bahkan, dapat dikatakan bahwa UU No. 7 Tahun 1992 ini merupakan pintu gerbang dimulainya perbankan syariah di Indonesia. Namun demikian, UU tersebut belum memberikan landasan hukum yang cukup kuat terhadap pengembangan bank syariah karena belum secara tegas mengatur mengenai keberadaan bank berdasarkan prinsip syariah, melainkan bank bagi hasil.
Sementara itu, pengertian "bank bagi hasil" yang dimaksudkan dalam undang-undang tersebut belum mencakup juga secara tepat pengertian bank syariah yang ternyata memiliki cakupan yang lebih luas dari bagi hasil itu sendiri, termasuk belum adanya ketentuan operasional yang secara lengkap mengatur kegiatan usaha bank syariah hingga sampai dengan tahun 1998. Setelah diberlakukannya UU No. 10 Tahun 1998 tentang perubahan UU No. 7 Tahun 1992 tentang Perbankan yang diikuti dengan dikeluarkannya sejumlah ketentuan pelaksanaan dalam bentuk SK Direksi BI baru dianggap telah mem- 
berikan landasan hukum yang lebih kuat dan kesempatan yang lebih luas bagi pengembangan perbankan syariah di Indonesia.

Ketentuan dalam undang-undang tersebut memberikan kesempatan yang lebih luas untuk pengembangan jaringan perbankan syariah antara lain melalui izin pembukaan Kantor Cabang Syariah (KCS) oleh bank umum konvensional. Selain itu UU No. 23 Tahun 1999 tentang Bank Indonesia juga menugaskan BI mempersiapkan perangkat peraturan dan fasilitas-fasilitas penunjang yang mendukung operasional bank syariah.

\section{B. Perkembangan Regulasi Bank Syari'ah di Indonesia}

Sejarah perkembangan Bank Syari'ah di Indonesia ditandai dengan munculnya lembaga perekonomian syari'ah. dilandasi oleh kehadiran dua gerakan renaissance Islam modern: neorevivalis dan modernis. ${ }^{1}$ Tujuan utama dari pendirian lembaga keuangan berlandaskan etika ini adalah sebagai upaya kaum muslimin untuk mendasari segenap aspek kehidupan ekonominya berlandaskan AlQuran dan Sunnah.

Pakistan dan Malaysia tercatat sebagai negara yang mula-mula melaksanakan sistem profit dan loss sharing sekitar tahun 1940-an, yaitu adanya upaya mengelola dana jemaah haji secara nonkonvensional. Perintis lainnya adalah Islamic Rural Bank di desa Mit Ghamr pada tahun 1963 di Kairo, Mesir. Setelah dua rintisan awal yang cukup sederhana di atas, bank Islam mulai menunjukkan pertumbuhan yang sangat pesat.

Pada bulan desember 1970 di Karachi, Pakistan, Menteri Luar Negeri Negara-negara Organisasi Konferensi Islam (OKI) mengadakan pertemuan dan pada kesempatan itu Mesir mengajukan sebuah proposal untuk mendirikan bank syari'ah. Proposal yang disebut Studi tentang Pendirian Bank Islam Internasional untuk Perdagangan dan Pembangunan (International Islamic bank for Trade and Development) atau sering disebut Islamic Development Bank (IDP) dan proposal

${ }^{1}$ Abdullah Saeed, Islamic Banking and Interest: A Study of the Prohibition of Riba and its Contemporary Interpretation (Leiden: EJ Brill. 1996), hlm. 9. pendirian Federasi Bank Islam (Federation of Islamic Banks), dikaji para ahli dari delapan belas negara Islam.

Proposal tersebut intinya mengusulkan bahwa sistem keuangan berdasarkan bunga harus digantikan dengan suatu sistem kerja sama dengan skema bagi hasil keuntungan maupun kerugian. Proposal tersebut diterima. Sidang menyetujui rencana mendirikan Bank Pembangunan Islam dan Federasi Bank Islam. ${ }^{2}$

Akhirnya Bank Pembangunan Islam atau Islamic Development Bank (IDB) baru disahkan pada sidang Menteri Keuangan OKI di Jeddah 1975 dengan modal awal 2 milliar dinar Islam atau ekuivalen 2 milliar SDR (Special Drawing Right). Semua negara OKI menjadi anggota IDB. Pada tahun-tahun awal beroperasinya, IDB mengalami banyak hambatan karena masalah politik. Meskipun demikian, jumlah anggotanya makin meningkat, dari 22 menjadi 43 negara. IDB juga terbukti mampu memainkan peran yang sangat penting dalam memenuhi kebutuhan-kebutuhan negara-negara Islam dalam pembangunan. Bank ini memberikan pinjaman bebas bunga untuk proyek infrastruktur dan pembiayaan kepada negara anggota berdasarkan partisipasi modal negara tersebut. Dana yang tidak dibutuhkan dengan segera digunakan bagi perdagangan luar negeri jangka panjang dengan menggunakan sistem murahabah dan ijarah. Sesuai dengan analisa Prof. Khursid Ahmad dan laporan Internasional Association of Islamic Bank, hingga akhir 1999 tercatat lebih dari dua ratus lembaga keuangan Islam yang beroperasi di seluruh dunia baik di negara-negara berpenduduk muslim maupun di Eropa, Australia dan Amerika. ${ }^{3}$

Sementara itu, penerapan sistem ekonomi Islam di Indonesia kaitannya dengan

${ }^{2}$ Eskarni Fushali, Ekonomi Islam Solusi Tepat untuk Kemaslahatan Umat, lihat dalam http://www.majalahsinar.com/index.php?option=com_content\&task= view\&id=92\&Itemid=76, diakses tanggal 13 Februari 2014.

${ }^{3}$ Lihat dalam review artikel kutipan dari http://www.majalahsinar.com/index.php?option=com_ content $\&$ task=view\&id $=92 \&$ Itemid $=76$, diakses tanggal 13 Februari 2014. 
perkembangan bank-bank syariah yang menerapkan sistem ekonomi Islam di beberapa negara timur tengah akhirnya mengusik pemikiran ekonom-ekonom Indonesia. Pada awal periode 1980-an, diskusi mengenai bank syariah sebagai pilar ekonomi Islam mulai dilakukan. Para tokoh yang terlibat dalam kajian tersebut adalah Karnaen A. Perwatatamadja, M. Dawam Rahardjo, A.M. Saefuddin, M. Amien Aziz, dan lain-lain. Beberapa uji coba pada skala yang relatif terbatas telah diwujudkan. Di antaranya adalah Baitut Tamwil-Salman, Bandung, yang sempat tumbuh mengesankan. Di Jakarta juga dibentuk lembaga serupa dalam bentuk koperasi, yakni Koperasi Redho Gusti.

Akan tetapi, prakarsa lebih khusus untuk mendirikan bank Islam di Indonesia baru dilakukan pada tahun 1990. Majelis Ulama Indonesia (MUI) pada tanggal 18-20 Agustus 1990 menyelenggarakan lokakarya Bunga Bank dan Perbankan di Cisarua, Bogor, Jawa Barat. Hasil lokakarya tersebut dibahas lebih mendalam pada Musyawarah Nasional IV MUI yang berlangsung di Hotel Sahid Jaya Jakarta, 22-25 Agustus 1990. Berdasarkan amanat Munas IV MUI, dibentuk kelompok kerja untuk mendirikan bank Islam di Indonesia. Kelompok kerja yang disebut Tim Perbankan MUI, bertugas melakukan pendekatan dan konsultasi dengan semua pihak terkait.

Lahirnya Bank Muamalat Indonesia adalah bukti kerja Tim Perbankan MUI yang telah dibentuk sebelumnya. Akte pendirian PT. Bank Muamalat Indonesia ditandatangani pada tanggal 1 November 1991. Pada saat penandatanganan akte pendirian ini terkumpul komitmen pembelian saham sebanyak Rp. 84 miliar. Pada tanggal 3 November 1991, dalam acara silaturahmi Presiden di Istana Bogor, dapat dipenuhi dengan total komitmen modal disetor awal sebesar Rp. 106.126.382$.000,00$. Dengan modal awal tersebut, pada tanggal 1 Mei 1992, Bank Muamalat Indonesia telah memiliki lebih 45 outlet yang tersebar di Jakarta, Bandung, Semarang, Surabaya, Balikpapan, dan Makasar. ${ }^{4}$

\footnotetext{
${ }^{4}$ Muhammad Syafi'i Antonio, Bank Syariah dari Teori ke Praktik (Jakarta: Gema Insani Press. 2001), hlm. 8.
}

Pada awal pendirian Bank Muamalat Indonesia, keberadaan bank syariah ini belum mendapat perhatian yang optimal dalam tatanan industri perbankan nasional. Landasan hukum operasi bank yang menggunakan sistem syariah hanya dikategorikan sebagai "bank dengan sistem bagi hasil"; tidak terdapat rincian landasan hukum syariah serta jenis-jenis usaha yang diperbolehkan. Hal ini sangat jelas tercermin dari UU No. 7 Tahun 1992, di mana pembahasan perbankan dengan sistem bagi hasil diuraikan hanya sepintas lalu dan merupakan "sisipan" belaka.

Di zaman reformasi, perkembangan perbankan syariah ditandai dengan disetu-juinya Undang-Undang No. 10 Tahun 1998. Dalam undang-undang tersebut diatur dengan rinci landasan hukum serta jenis-jenis usaha yang dapat dioperasikan dan diimplementasikan oleh bank syariah. Undang-undang tersebut juga memberikan arahan bagi bank-bank konvensional untuk membuka cabang syariah atau bahkan meng-konversi diri secara total menjadi bank syariah.

Perbedaan mencolok yang mengharuskan dibentuknya UU tersendiri di luar UU Perbankan yang telah ada (UU No. 7 tahun 1999 sebagaimana yang telah direvisi dengan UU No. 10 tahun 1999 tentang Perbankan) di antaranya adalah banyaknya jenis jasa bank syariah yang tidak dapat ditawarkan karena terpentok aturan perbankan yang sudah ada. Adanya batasan praktek perbankan dalam Pasal 6 dan 7 UU Perbankan yang melarang bank melakukan penyertaan modal, kecuali pada bank atau perusahaan lain di bidang keuangan. Hal ini tentu bertolak belakang dengan praktek bank syariah.

Salah satu jenis usaha bank syariah adalah melakukan transaksi penjualan antara lain dalam bentuk yang disebut murâbahah. Ini bertolak belakang jika bank syariah dilarang melakukan usaha yang menjadi fokus usahanya. Transaksi murâbahah adalah jasa pembiayaan yang mengambil bentuk transaksi dengan cicilan di mana harga barang harus telah terlunasi ketika barang diserahkan. Dalam prakteknya bank syariah seharusnya juga dapat melakukan leasing yang 
menurut UU Perbankan tidak boleh dilakukan oleh bank. ${ }^{5}$

Pada saat ini, berbagai produk syariah ditawarkan kepada masyarakat. Perbankan syariah antara lain menawarkan, simpanan amanah, tabungan dan deposito wadi'ah (titipan), tabungan dan deposito mudlârabah (bagi hasil), pembiayaaan mudlârabah, pembiayaan musyârakah (pembiayaan bersama), dan pembiayaan al-bay' bi Tsaman Ajil (pembelian barang oleh bank dan dijual kepada nasabah dengan menaikkan harganya).

Tentu saja, hal ini menuntut dibentuknya UU tersendiri bagi bank syariah di luar ketentuan Perbankan yang telah ada. Selain ada masalah ada dataran prakteknya, sistem akuntansi antara bank syariah juga perbedaan dengan bank konvensional. Sehingga laporan keuangan, yakni neraca laba/rugi dari bank syariah akan berbeda dengan yang konvensional. Adanya hambatan praktek yang dihadapi bank syariah diakui Bank Indonesia (BI). Nasirwan, salah seorang peneliti dalam Tim Penelitian dan Pengaturan Biro Perbankan Syariah BI, mengemukakan bahwa BI tidak menutup mata terhadap berbagai hambatan yang dihadapi perbankan syariah.

Namun begitu, BI kini menerapkan perlakuan khususnya terhadap bank-bank syariah. Hal ini merupakan konsekuensi logis dari perbedaan karakteristik antara bank konvensional dengan bank syariah. Tapi bukan merupakan kemudahan/fasilitas bagi bank syariah. Misalnya BI mengizinkan modifikasi dari sistem musyarakah sehingga bisa comply dengan UU Perbankan yang ada.

Kaitannya dengan perlunya regulasi khusus berupa UU Bank Syariah, BI pun mempunyai pendapat bahwa diperlukan menyusun sebuah draft UU Perbankan Syariah. Draft itu perlu segera disusun dan disosialisasikan dalam beberapa waktu ke depan mengingat tujuan dari pengembangan bank syari'ah kini telah diatur oleh BI melalui pembentukan Direktorat Perbankan Syariah yang sebelumnya pengurusan dan pengembangan bank

${ }^{5}$ Tri Hartanto, Sebuah Keharusan Undang-undang Khusus Bank Syari'ah, lihat penjelasan lengkapnya dalam http://www.hukumonline.com/detail.asp?id=9235\&cl=Berita, diakses tanggal 13 Februari 2014. syariah di BI hanya ditangani oleh bagian setingkat Biro. Berikut ini tabel perkembangan regulasi bank syariah. ${ }^{6}$

Tabel

Perkembangan Regulasi Bank Syariah di Indonesia

\begin{tabular}{|c|c|}
\hline Tahun & Perkembangan \\
\hline 1990 (Lokakarya MUI) & Kesepaka tan untuk membentuk bank syariah \\
\hline $\begin{array}{l}1992 \text { (Pengenalan dual } \\
\text { bangking system) }\end{array}$ & $\begin{array}{l}\text { UU No. } 7 \text { tahun } 1992 \text { tentang Perbankan ya ng memberikan } \\
\text { kesempatan opera si bagi hasil } \\
\text { Bank Muama lat sebagai bank sya riah pertama seba gai hasil } \\
\text { kongres MUI }\end{array}$ \\
\hline $\begin{array}{l}1998 \text { (Pengenala dual } \\
\text { system bank) }\end{array}$ & $\begin{array}{l}\text { UU No. } 10 \text { ta hun } 1998 \text {, Bl mengakuikeberada an bank syariah } \\
\text { dan bank konvensional } \\
\text { Bank konvensional diperkenankan membuka kantor cabang } \\
\text { syariah }\end{array}$ \\
\hline $\begin{array}{l}1999 \text { (Pengenalan } \\
\text { instrumen moneter } \\
\text { syariah) }\end{array}$ & $\begin{array}{l}\text { UU No. } 23 \text { tahun1999; Bl berta ng gung jawab terhadap } \\
\text { pengaturan dan pengawa san perbankan tema suk bank } \\
\text { syariah } \\
\text { Biberwenang untuk menetapkan kebijakan moneter } \\
\text { berdasarkan prinsip sya riah } \\
\text { Berdirinya bank umum syariah kedua } \\
\text { Dibukanya unit usaha syariah pertama }\end{array}$ \\
\hline $\begin{array}{l}2000 \text { (Pengenalan pasar } \\
\text { uang syariah) }\end{array}$ & $\begin{array}{l}\text { Penyusuna n peraturan perbankan syaria h oleh BI } \\
\text { Pengenalan instrumen pa sa r uang syariah }\end{array}$ \\
\hline $\begin{array}{l}2002 \text { (Penyempurna an } \\
\text { jaringan kantor) }\end{array}$ & $\begin{array}{l}\text { PBIN 0. 4/1/2002: } \\
\text { Konversi BUK menjadi BUS } \\
\text { Konversi KCKmenjadi KCS } \\
\text { Konversi KCP/KK menjadi KCS } \\
\text { Membuka KCPS di KCK } \\
\text { Membuka unit syariah (US) di KCK }\end{array}$ \\
\hline
\end{tabular}

Sejauh ini berdasarkan survei persepsi pada tahun 2000-2001 yang dilakukan BI, potensi perkembangan bank syariah cukup menggembirakan. Berdasarkan survei dari total enam propinsi yang rata-rata populasinya muslimnya 97 persen, terdapat 42 persen yang menganggap sistem bunga bertentangan dengan ajaran agama. Sedangkan yang memahami produk jasa dan manfaat bank syariah berjumlah 11 persen.

Persentase 42 persen persepsi masyarakat bahwa bunga haram merupakan potensi yang besar bagi pengembangan bank syariah. Pasalnya, masyarakat sangat mengharapkan alternatif pilihan untuk melakukan investasi yang didasarkan atas syariah. Karenanya, sistem bagi hasillah (profit loss sharing) yang merupakan motor pengerak bank syariah menjadi pilihan utama umat. Bahkan kini setelah produk ATM Bersama dilakukan melalui kerjasama antara Bank Muamalat Indonesia dengan bank-bank lainnya semakin meningkatkan partisipasi masyarakat menjadi nasabah bank syari'ah bersamaan dengan

${ }^{6}$ Dikutip dari situs resmi Bank Indonesia http:// bi.co.id. 
tumbuhnya kepercayaan mereka kepada bank syari'ah.

\section{Latar Belakang Dilegislasikannya No. 10 Tahun 1998}

Latar belakang dilegislasikannya UU No. 10 Tahun 1998 tentang Perbankan, antara lain:

\section{Historis}

Secara historis, proses legislasi UU No. 10 Tahun 1998 tentang Perbankan tidak serta merta karena alasan politik, tetapi merupakan respon dari tuntutan masyarakat yang berangsung sejak negara ini merdeka. Seperti telah dijelaskan dalam uraian sebelumnya tentang perkembangan regulasi perbankan syari'ah di Indonesia, tampak dari periode pemerintahan Orde Baru melakukan beberapa kebijakan penting yang terkait dengan bank syari'ah. Misalnya saja, diyakini bahwa pemerintahan Orde Baru memberi dukungan positif bagi didirikannya bank syari'ah lebih dari sekedar tuntutan politik, tetapi yang paling utama adalah mereson tuntutan dan kebutuhan masyarakat akan kehadiran lembaga perbankan syari'ah di Indonesia.?

Lahirnya UU No. 7 Tahun 1992 tentang Perbankan secara implisit telah membuka peluang kegiatan usaha perbankan yang memiliki dasar operasional bagi hasil yang secara rinci dijabarkan dalam Peraturan Pemerintah No. 72 Tahun 1992 tentang Bank Berdasarkan Prinsip Bagi Hasil. Ketentuan perundang-undangan tersebut telah dijadikan sebagai dasar hukum beroperasinya bank syariah di Indonesia yang menandai dimulainya era sistem perbankan ganda (dual banking system) di Indonesia.

Dalam periode 1992 sampai dengan 1998 , terdapat hanya satu bank umum syariah dan 78 bank perkreditan rakyat syariah (BPRS) yang telah beroperasi. Pada tahun 1998, dikeluarkan UU No. 10 Tahun 1998 sebagai amandemen dari UU No. 7 Tahun 1992 tentang Perbankan yang memberikan landasan hukum yang lebih kuat bagi keberadaan sistem perbankan syariah. Hingga pada tahun

\footnotetext{
${ }^{7}$ Rachmat Syafe'i, Tinjauan Yuridis Terhadap Perbankan Syari'ah dalam Harian Umun Pikiran Rakyat edisi 21 Maret 2005 dan lihat pula dalam http://www.pikiran-rakyat.com/cetak/2005/0305/21/0802.htm, diakses tanggal 20 Februari 2014.
}

1999 setelah dikeluarkan UU No. 23 Tahun 1999 tentang Bank Indonesia yang memberikan kewenangan kepada Bank Indonesia untuk dapat menjalankan tugasnya berdasarkan prinsip syariah. Kini, industri perbankan syariah telah berkembang lebih cepat setelah kedua perangkat perundangundangan tersebut diberlakukan.

\section{Filosofis}

Secara filosofis, sistem ekonomi syariah menekankan konsep manfaat pada kegiatan ekonomi yang lebih luas lagi, bukan hanya pada manfaat di setiap akhir kegiatan, akan tetapi juga pada setiap proses transaksi. Setiap kegiatan termasuk proses transaksi harus mengacu pada konsep maslahat dan menjunjung tinggi asas keadilan. Prinsip ini juga menekankan para pelaku ekonomi untuk selalu menjunjung tinggi etika dan norma hukum dalam kegiatan ekonomi. Prinsip umum ini dijabarkan pada tingkat praktis yakni operasional bank berbasis syari'ah.

Sebagai realisasi dari konsep syariah, pada dasarnya sistem ekonomi/perbankan syariah memiliki tiga ciri yang mendasar yaitu prinsip keadilan, menghindari kegiatan yang dilarang dan memperhatikan aspek kemanfaatan. Oleh karena itu, keseimbangan antara memaksimalkan keuntungan dan pemenuhan prinsip syariah menjadi hal yang mendasar bagi kegiatan operasional bank syariah. Dalam hal pelaksanaannya, prinsip ekonomi syariah akan tercermin dalam nilai-nilai yang secara umum dapat dibagi dalam dua perspektif yaitu mikro dan makro. Nilai-nilai syariah dalam perspektif mikro menekankan aspek kompetensi/profesionalisme dan sikap amanah.

Di samping itu, dari perspektif makro nilai-nilai syariah menekankan aspek distribusi, pelarangan riba dan kegiatan ekonomi yang tidak memberikan manfaat secara nyata kepada sistem perekonomian. Dengan demikian, dapat dilihat secara jelas potensi manfaat keberadaan sistem perekonomian/perbankan syariah yang ditujukan bukan hanya untuk umat muslim, akan tetapi bagi seluruh umat manusia (rahmatan lil 'alamin rahmat bagi alam semesta). ${ }^{8}$

\footnotetext{
${ }^{8}$ Nur Fakhrus Salis, Penerapan dan Pengembangan Prinsip Syari'ah di Lembaga Keuangan Syari'ah, kutipan
} 
Dilihat dari segi tujuannya, UU No. 10 Tahun 1998 tentang Perbankan ini ditujukan menjadi hukum materil bagi pengembangan dan eksistensi bank syari'ah di Indonesia. Sejak awal pembentukannya, UU No. 10 Tahun 1998 tentang Perbankan lahir dari UU sebelumnya (UU No. 7 tahun 1992) yang dianggap kurang menampung regulasi syari'ah dalam mekanisme perbankan di Indonesia.

Dalam rangka mewujudkan sistem perbankan syari'ah yang sehat, kuat dan efisien untuk mencapai stabilitas sistem keuangan dan mendorong pembangunan ekonomi nasional, Bank Indonesia telah menyusun beberapa kebijakan bagi penguatan bank syari'ah dengan tujuan sebagai berikut:

a. Terciptanya struktur perbankan syari'ah yang sehat, yang mampu mendorong pembangunan nasional secara berkesinambungan;

b. Terbentuknya industri perbankan syari'ah yang memiliki ketahanan dalam menghadapi risiko;

c. Terciptanya good syari'ah corporate governance;

d. Terbentuknya sistem pengaturan dan pengawasan perbankan syari'ah yang efektif dan efisien;

e. Terwujudnya infrastruktur yang lengkap dan dapat mendukung efisiensi operasional sistem perbankan syari'ah;

f. Terwujudnya pemberdayaan dan perlindungan konsumen pengguna jasa perbankan syari’ah.

\section{Sosiologis}

Kenyataan yang ada di masyarakat menunjukkan bahwa dalam periode krisis ekonomi, perbankan syariah memiliki daya tahan yang relatif lebih kuat. Berkaitan dengan itu perbankan syariah diharapkan dapat berperan lebih besar dalam proses pemulihan perekonomian Sehingga eksistensi bank syari'ah yang kokoh hingga saat ini tidak dapat dilepaskan dari faktor kepercayaan dari masyarakat itu sendiri.

Keadaan semacam ini tentunya perlu diikuti dengan adanya regulasi bank syari'ah

dari makalah Nur Fakhrus Salis, mahasiswa Jurusan Perbankan Syari'ah di STAIN Pekalongan. dan sekaligus melakuakan upaya untuk mendorong pertumbuhan industri perbankan syariah yang masih berada dalam tahap awal pengembangan. Beberapa hal penting yang perlu mendapatkan perhatian, antara lain:

a. Kerangka dan perangkat pengaturan perbankan syariah belum lengkap;

b. Cakupan pasar masih terbatas;

c. Kurangnya pengetahuan dan pemahaman mengenai produk dan jasa perbankan syariah;

d. Institusi pendukung yang belum lengkap dan efektif;

e. Efisiensi operasional perbankan syariah yang masih belum optimal;

f. Porsi skim pembiayaan bagi hasil dalam transaksi bank syari'ah masih perlu ditingkatkan;

g. Kemampuan untuk memenuhi standar keuangan syariah internasional.

Berkenaan dengan hal tersebut, beberapa pertimbangan sosiologis mengapa diperlukan dilegislasikan UU No. 10 Tahun 1998 tentang Perbankan di Indonesia dapat dilihat dari konsideran UU No. 10 Tahun 1998 tentang Perbankan, yaitu: ${ }^{9}$

a. Bahwa pembangunan nasional merupakan upaya pembangunan yang berkesinambungan dalam rangka mewujudkan masyarakat Indonesia yang adil dan makmur berdasarkan Pancasila dan Undang-Undang Dasar 1945;

b. Bahwa dalam menghadapi perkembangan perekonomian nasional yang senantiasa bergerak cepat, kompetitif, dan terintegrasi dengan tantangan yang semakin kompleks serta sistem keuangan yang semakin maju, diperlukan penyesuaian kebijakan di bidang ekonomi, termasuk Perbankan;

c. Bahwa dalam memasuki era globalisasi dan dengan telah diratifikasinya beberapa perjanjian internasional di bidang perdagangan barang dan jasa, diperlukan penyesuaian terhadap peraturan perundang-undangan di bidang perekonomian, khususnya sektor Perbankan;

${ }^{9}$ Lihat Konsideran Undang-Undang Nomor 10 Tahun 1998 tentang Perbankan. 
d. Bahwa berdasarkan pertimbangan tersebut pada huruf $a$, huruf $b$, dan huruf $c$ di atas, dipandang perlu mengubah Undang-undang Nomor 7 Tahun 1992 tentang Perbankan dengan Undang-undang.

\section{Politik}

Perbankan syariah merupakan industri yang baru yang membutuhkan suatu keahlian dan pengetahuan yang khusus. Kurangnya dukungan keahlian yang memadai pada akhirnya akan membahayakan kesinambungan operasi perbankan dalam jangka panjang. Bank Indonesia sebagai otoritas perbankan syariah, bersama stakeholder lainnya memberikan beberapa kebijakan politis untuk mendorong penguatan lembaga perbankan syari'ah di Indonesia. Bahkan BI mendukung peningkatan kualitas SDI melalui programprogram training yang ditujukan untuk: ${ }^{10}$

a. Staf dari bank yang tertarik untuk beroperasi sesuai prinsip syariah dan juga staf dari satuan kerja terkait di Bank Indonesia;

b. Mahasiswa dari perguruan tinggi dan lembaga akademis lainnya, yang diharapkan dapat menjadi calon sumber daya insani di perbankan syariah atau paling tidak dapat menjadi calon pengguna produk dan jasa perbankan syariah;

c. Pengajar dari perguruan tinggi dan lembaga akademis lainnya, untuk mensosiali-sasikan konsep perbankan syariah sebagai bagian dari kurikulum, silabus dan pengembangan program studi khusus.

Sesuai dengan sifat transaksinya, sistem keuangan syariah merupakan fenomena kegiatan ekonomi riil. Oleh karena itu, di dalam kegiatan operasionalnya, sistem perbankan/keuangan syariah perlu mendapatkan dukungan lembaga pemerintah lainnya dan lembaga-lembaga pendukung terkait baik di dalam dan di luar negeri yang secara signifikan dapat meningkatkan efisiensi operasi. Beberapa lembaga domestik terkait yang

\footnotetext{
${ }^{10}$ Nur Fakhrus Salis, Penerapan dan Pengembangan Prinsip Syari'ah di Lembaga Keuangan Syari'ah, kutipan dari makalah Nur Fakhrus Salis, mahasiswa Jurusan Perbankan Syari'ah di STAIN Pekalongan.
}

dapat disebutkan sebagai contoh misalnya perguruan tinggi, Biro Pusat Statistik, Otoritas Pasar Modal, lembaga rating dan lembaga Zakat Infaq dan Sadaqah.

Salah satu aspek terpenting dalam pengembangan perbankan syariah adalah tersedianya lembaga hukum yang mampu menangani setiap permasalahan hukum yang timbul dari transaksi keuangan syariah secara lebih efisien dan efektif serta sejalan dengan nilai-nilai syariah. Penanganan kasus keuangan yang berlarut-larut pada akhirnya akan mempengaruhi kondisi likuiditas perbankan dan bahkan dapat menimbulkan insolvensi. Pemahaman yang benar mengenai kondisi, sifat dan karakteristik perbankan syariah oleh masyarakat akan sangat membantu dalam upaya meningkatkan kestabilan sistem perbankan/keuangan syariah.

Hal tersebut dapat dipahami karena dengan semakin meningkatnya pengetahuan pasar akan kondisi riil perbankan syariah, kondisi panik yang dapat menyebabkannya bank run dapat dicegah. Hal tersebut dapat mulai dirintis dengan pembentukan suatu forum yang dapat secara efektif mengkomunikasikan (secara dua arah) arah dan perkembangan bank syariah secara aktual. Pembentukan forum semacam ini juga sangat sesuai dengan semangat tabligh yang bertujuan untuk melakukan syi'ar secara berkesinambungan.

\section{Yuridis}

Pada tahun 1998, sejak diberlakukannya UU No. 10 Tahun 1998 tentang perubahan UU No. 7 Tahun 1992 tentang Perbankan, yang diikuti dengan dikeluar-kannya sejumlah ketentuan pelaksanaan dalam bentuk SK Direksi BI baru dianggap telah memberikan landasan hukum yang lebih kuat dan kesempatan yang lebih luas bagi pengembangan perbankan syariah di Indonesia. Perundang-undangan tersebut membe-rikan kesempatan yang lebih luas untuk pengembangan jaringan perbankan syariah antara lain melalui izin pembukaan Kantor Cabang Syariah (KCS) oleh bank umum konvensional dengan cara dual banking system.

Dual Banking System yang dimaksud adalah terselenggaranya dua sistem perbankan (konvensional dan syariah secara berdampingan) yang pelaksanaannya diatur da- 
lam berbagai peraturan perundang-undangan yang berlaku. Sehingga yang terjadi adalah bank syariah tidak berdiri sendiri (mandiri) dalam operasionalisasinya di mana masih menginduk kepada bank konvensional. Bila demikian adanya perbankan syariah hanya menjadi salah satu bagian dari program pengembangan bank konvensional, padahal yang dikehendaki adalah bank syariah yang betul-betul mandiri dengan berbagai perangkatnya sebagai bagian perbankan yang diakui secara nasional.

Ada beberapa dasar hukum (juridical matters) yang menjadi patokan dasar dilegislasikannya UU Perbankan, antara lain dapat dilihat dari konsideran UU No. 10 Tahun 1998 tentang Perbankan, antara lain: ${ }^{11}$

a. Pasal 5 ayat (1), Pasal 20 ayat (1), Pasal 23, dan Pasal 33 Undang-undang Dasar 1945;

b. Undang-undang Nomor 13 Tahun 1968 (Lembaran Negara Tahun 1968 Nomor 63, Tambahan Lembaran Negara Nomor 28651);

c. Undang-undang Nomor 7 Tahun 1992 (Lembaran Negara Tahun 1992 Nomor 31, Tambahan Lembaran Negara Nomor 34721).

\section{Proses Transformasi Hukum Islam d- alam UU Perbankan}

Dewasa ini, fikih bukanlah sebuah norma hukum yang pasif dan berada dalam kerangka teoritis semata, tetapi dapat dimplementasikan ke dalam berbagai dimensi kehidupan. Salah satunya adalah implementasi fikih muamalah sebagai ketentuan hukum Islam yang mengatur tentang hukum-hukum ekonomi ke dalam pranata ekonomi sejenis lembaga-lembaga ekonomi dan keuangan syari'ah baik bank maupun non bank.

Pada dataran teknis, lembaga keuangan syari'ah menerapkan manajemen dan operasional berdasarkan prinsip-prinsip fikih muamalah, antara lain:

\section{Prinsip Mudlârabah}

Implementasi prinsip mudlârabah di lembaga keuangan syari'ah berdasar kepa-

${ }^{11}$ Lihat Konsideran Undang-Undang Nomor 10 Tahun 1998 tentang Perbankan. da ketentuan mudlârabah yang ditetapkan dalam Al-Quran, Sunnah, ijma', dan qiyash. ${ }^{12}$ Secara umum, Al-Quran telah menetapkan keabsahan prinsip mudha-rabah ini dalam Surat Al-Muzammil ayat 20 yang berbunyi:

$$
\text { وءاخرون يضربون فن الأرضى يبتغون من فضل الله }
$$

“Dan sebagian dari mereka orang-orang yang berjalan di muka bumi, mencari sebagian dari karunia Allah"

Dipertegas pula dalam surat Al-Jumû'at ayat 10:

$$
\text { فاءذا قضيت الصلوة فانتشروا في الأرض وابتغوا من فضل }
$$

"Maka apabila telah sembahyang, maka bertebaranlah kamu di muka bumi dan carilah karunia (rizki) Allah".

Sedangkan al-Sunah yang menetapkan mudlârabah tersebut dalam riwayat Ibn Abbas yang menyatakan bahwa Abbas ibn Abd al-Muthallib apabila menyerahkan harta dengan cara mudlârabah menetapkan syarat kepada kawannya (mudhârib) untuk tidak membawa hartanya menyeberangi lautan, mengarungi lembah yang berbahaya, atau dibelikan ternak yang paru-parunya basah. Jika yang bersangkutan melanggarnya, maka ia pun harus bertanggung jawab atas pelanggarannya itu. Hal demikian disampaikan kepada Rasulullah SAW dan beliau pun membenarkannya. Selain riwayat ini, masih banyak ditemukan riwayat-riwayat lain yang telah membenarkan prinsip mudlârabah ini. Untuk lebih rincinya bisa dilihat secara langsung dalam kitab-kitab fikih.

Sedangkan dasar hukum ijma' adalah hadits riwayat Jama'ah dari beberapa shahabat yang menjelaskan bahwa mereka telah menyerahkan harta anak yatim dengan cara mudlârabah dan tak ada seorangpun shahabat yang menentangnya. Ketiadaan shahabat yang menentang atas perilaku

${ }^{12}$ Wahbah al-Zuhayly, Al-Figh al-Islâmi wa Adillatuh (Beyrut: Dâr al-'Ilm. 1984), hal. 837. 
shahabat itu merupakan salah satu bentuk dari ijma'.

Selain didasarkan kepada Al-Quran, Sunnah, dan ljma', keabsahan mudha-rabah pun didasarkan kepada qiyash (analogi). Prinsip Mudlârabah ini dapat dianalogikan pada musyaqqah, yang telah jelas disepakai keabsahannya. Antara mudlârabah dengan musyaqah ini memiliki kesamaan illat hukum, yakni sama-sama dibutuhkan oleh manusia untuk mendayagunakan harta. Istilah mudlârabah itu sendiri diambil dari kata al-dharb fî al-ardh (berjalan di muka bumi). Penamaan mudlârabah ini disebabkan dharib harus berjalan jauh di muka bumi untuk melakukan kegiatan komersial dengan maksud mencari keuntungan. ${ }^{13}$

Dalam literatur Islam telah ditemukan dua istilah yang memiliki kesamaan makna, yaitu mudlârabah dan qirâdh. Dalam sejarahnya, istilah mudlârabah biasa digunakan oleh penduduk Irak, sedangkan istilah qiradh biasa digunakan oleg penduduk Hijaz. Secara bahasa qiradh ini diambil dari kata Qardl yang berarti qath' (potongan), karena pemilik harta (rabb al-mal) memotong sebagian hartanya untuk diserahkan kepada pekerja ('âmil) agar ber-tasharruf pada harta tersebut dan 'amil juga memotong sebagian keuntungan yang diperolehnya untuk diserahkan kepada rabb al-mâl.

Selain itu, prinsip ini pun dinamakan juga dengan mudlârabah, karena rabb al-mâl dan 'âmil sama-sama meletakkan sahamnya dalam keuntungan. Penggunaan istilah ini disebabkan pula karena dalam perniagaannya 'âmil membutuhkan perjalanan (safar), sementara safar dalam perniagaan oleh AlQuran disebut dengan dharb fî al-ardh. ${ }^{14}$ Sedangkan makna mudlârabah atau qiradh secara terminologi adalah sebuah prinsip di mana pemilik modal ( $\mathrm{rab}$ al-mal) menyerahkan hartanya kepada pekerja ('âmil) agar berniaga dengan harta tersebut, di mana keuntungan dapat dibagi di antara kedua orang yang bertransaksi sesuai prosentase yang telah disepakati sebelumnya.

\footnotetext{
${ }^{13}$ Afzalur Rahman, Doktrin Ekonomi Islam (Yogyakarta: Dana Bhakti Wakaf. 1996), hlm. 382.

${ }^{14}$ Wahbah al-Zuhayly, Al-Fiqh al-Islâmi. hal. 836.
}

Menurut Wahbah al-Zuhayly, bahwa yang dimaksud dengan mudlârabah adalah pemilik (mâlik) menyerahkan harta kepada pekerja ('âmil) untuk berniaga pada harta itu dengan keuntungan diserikatkan di antara keduanya atas perhitungan tertentu, sedangkan bila rugi maka kerugian itu ditanggung sepenuhnya oleh pemilik harta. ${ }^{15}$

Dari pengertian tersebut dapat dipahami bahwa dalam mudlârabah ada enam unsur (rukun) yang harus terpenuhi, yakni prinsip, rabb al-mâl (pemilik harta atau modal), 'âmil (pekerja atau pengusaha), mâl (harta atau modal), 'amal (jenis usaha atau pekerjaan yang dilakukan oleh 'âmil), dan pembagian keuntungan.

Di bank syari'ah, prinsip mudlârabah ini digunakan sebagai salah satu prinsip operasional. Secara operasional, prinsip mudlârabah di bank Islam diartikan sebagai perjanjian kesepakatan bersama antara pemilik modal dan pengusaha dengan ketentuan pihak pemilik modal menyediakan dana dan pihak pengusaha memutar modal dengan dasar bagi hasil keuntungan. Dalam prinsip ini kedua belah pihak sama-sama menanggung resiko sesuai dengan kerugian dan keuntungannya. ${ }^{16}$

Prinsip mudlârabah ini secara aplikatif diwujudkan dalam bentuk produk perbankan. Produk perbankan yang menggunakan prinsip mudlârabah antara lain tabungan mudharabah, deposito mudharabah, dan pembiayaan mudharabah. Tabungan Mudharabah adalah dana yang disimpan nasabah yang akan dikelola bank untuk memperoleh keuntungan dengan sistem bagi hasil sesuai dengan kesepakatan bersama. Dana yang disimpan melalui produk ini bisa diambil sewaktu-waktu oleh nasabah penyimpan.

Pada prinsipnya, variabel yang menentukan prinsip bagi hasil dalam produk tersebut hampir sama dengan deposito investasi mudlârabah. Namun, disebabkan dana yang disimpan dapat diambil sewaktu-waktu, maka variabel besarnya simpanan diperhitungkan me-

\footnotetext{
${ }^{15}$ Ibid. hlm. 836-837.

${ }^{16}$ Yadi Janwari, Lembaga-Lembaga Perekonomian Syari'ah (Bandung: Pustaka Mulia dan Fakultas Syari'ah IAIN Sunan Gunung Djati. 2000), hlm. 18-19.
} 
nurut saldo rata-rata. Dengan kata lain, tingkat fluktuasi dana tabungan juga ikut menentukan besar kecilnya laba yang diperoleh bank. ${ }^{17}$ Sedangkan yang dimaksud dengan deposito mudharabah adalah dana simpanan nasabah yang hanya bisa ditarik berdasarkan jangka waktu yang telah ditentukan. Dalam produk ini nasabah ikut menanggung keuntungan dan kerugian yang dialami oleh bank (profit and loss sharing). Dalam produk deposito tersebut, nasabah memiliki hak untuk memperoleh keuntungan sesuai dengan peranan dananya dalam pembentukan laba bank. Variabel yang paling menentukan besar kecilnya rasio pembagian laba bergantung pada besarnya dana yang diinvestasikan, jangka waktu penyimpanan, dan keuntungan Bank Islam selama periode tertentu. ${ }^{18}$

Pembiayaan mudharabah adalah bank menyediakan pembiayaan modal investasi atau modal kerja secara penuh (trusty financing), sedangkan nasabah menyediakan proyek atau usaha lengkap dengan manajemennya. Hasil keuntungan dan kerugian yang dialami nasabah dibagikan atau ditanggung bersama antara bank dan nasabah dengan ketentuan sesuai kesepakatan bersama. Selanjutnya, pada saat jatuh tempo nasabah berkewajiban mengembalikan modal kepada bank, baik dengan cara dicicil atau dilunasi seluruhnya. Pemberlakuan prinsip bagi hasil antara pihak nasabah dengan bank berlangsung selama modal yang diberikan bank belum dikembalikan seluruhnya. ${ }^{19}$

\section{Prinsip Musyârakah}

Seperti halnya pembahasan aplikasi mudlârabah di atas, dalam pembahasan aplikasi musyarakah dalam lembaga ekonomi syari'ah pun akan dideskripsikan terlebih dahulu hakikat dari musyarakah itu sendiri. Keabsahan musyârakah ini ditetapkan berdasarkan Al-Quran, Sunnah, dan ljma'. Secara umum, Al-Quran yang menetapkan keabsahan musyarakah ini adalah surat al-Shad ayat 24:

\footnotetext{
${ }^{17}$ Ibid. hlm. 21.

${ }^{18}$ Ibid. hlm. 21.

${ }^{19}$ lbid. hlm. 22.
}

$$
\begin{aligned}
& \text { وانّ كثيرا من الخلطاء ليبغى بعضهم على بعض الاّ الذين } \\
& \text { آمنوا وعملوا الصالحات }
\end{aligned}
$$

“...... dan sesungguhnya kebanyakan dari orang-orang yang berkongsi itu sebagian mereka berbuat zhalim kepada sebagian yang lain, kecuali orang-orang yang beriman dan mengerjakan amal shalih".

Sedangkan Sunnah yang menetapkan keabsahan musyârakah adalah sebuah hadits Qudsi yang diriwayatkan oleh Abû Hurayrah yang menyatakan Rasulullah SAW telah bersabda bahwa Allah SWT berfirman: "Aku adalah pihak ketiga di antara dua pihak yang sedang berserikat selama salah satu dari mereka tidak mengkhinati yang lain. Seandainya berkhianat, maka Aku keluar dari penyertaan itu". Selain Al-Quran dan Sunnah, keabsahan prinsip musyarakah tersebut juga ditetapkan melalui ijma'. Ibn Qudamah menyatakan bahwa kaum muslimin telah bersepakat tentang keabsahan prinsip musyârakah ini, sekalipun ditemukan perbedaan dalam beberapa hal. ${ }^{20}$

Musyârakah dalam literatur fikih sering disebut pula dengan syirkah. Syirkah secara bahasa berarti ikhtilath atau khalath (campuran). Sedangkan secara istilah, menurut Wahbah al-Zuhayly, berarti seseorang mencampur hartanya dengan yang lain di mana keduanya tidak bercerai satu sama lain. ${ }^{21}$ Pengertian ini hampir senada dengan pengertian Sayyid Sâbiq bahwa syirkah adalah prinsip antara dua orang yang berserikat pada modal dan keuntungan. ${ }^{22}$

Dari pengertian itu dapat dipahami bahwa di dalam prinsip syirkah terdapat beberapa unsur yang harus ada, di antaranya yaitu dua orang yang berserikat (syarîkayn), modal yang diserikatkan (ra's al-mâl), pekerjaan ('amal), dan keun-tungan (ribh). Keempat komponen tersebut ada dalam frame rukun syirkah.

\footnotetext{
${ }^{20} \mathrm{Ibn}$ Qudamah, Al-Mughni (Beirut: Dâr al-Fikr. 1981), hlm. 109.

${ }^{21}$ Wahbah al-Zuhayly, Al-Fiqh al-Islâmi. hlm. 792.

${ }^{22}$ Sayyid Sâbiq, Fiqh al-Sunnah (Beirut: Dâr al-Fikr. 1984), hlm. 294.
} 
Kemudian, bagaimana mengimplementasikan syirkah atau musyârakah ini di dalam lembaga ekonomi syari'ah kontemporer? Seperti halnya prinsip mudlârabah, hampir semua lembaga ekonomi dan keuangan syari'ah kontemporer menggunakan prinsip musyarakah sebagai salah satu prinsip operasionalnya.

Di bank syari'ah, prinsip musyarakah ini digunakan sebagai prinsip operasional dengan pengertian perjanjian kesepakatan bersama antara beberapa pemilik modal untuk menyertakan modal sahamnya pada satu proyek, yang biasanya berjangka waktu panjang. ${ }^{23}$ Secara riil, prinsip musyarakah ini hanya diaplikasikan dalam produk pengerahan dana pada masyarakat, yakni dalam produk Pembiayaan Musyarakah. Pembiayaan Musyarakah ini berarti pembiayaan sebagian dari modal usaha, yang mana pihak bank dapat dilibatkan dalam proses manajemennya. Sedangkan pembagian keutnungan dalam bentuk Pembiayaan Musyarakah ini ditentukan dalam perjanjian sesuai dengan proporsi masing-masing pihak, yakni antara bank dan nasabah penerima pembiayaan. ${ }^{24}$

\section{Prinsip Wadi'ah}

Secara bahasa, wadi'ah dapat diartikan sesuatu yang diletakan pada selain pemiliknya agar dipelihara atau dijaga. ${ }^{25}$ Wadi'ah ini merupakan nama yang berlawanan antara memberikan harta untuk dipelihara dengan penerimaan yang merupakan mashdar dari awda' $a$ ('ida') yang berarti titipan dan membebaskan barang yang dititipkan. ${ }^{26}$ Sedangkan pengertian wadi'ah secara istilah, para fuqaha berbeda dalam redaksi definisi. Walaupun begitu, makna substantif dari definisi yang dikemukakan fuqaha itu tidak jauh berbeda, atau bahkan sama. Madzhab Hanafi mengartikan wadi'ah dengan penguasaan hlm. 19.

${ }^{23}$ Yadi Janwari, Lembaga-Lembaga Perekonomian.

${ }^{24}$ Ibid. hlm. 23.

${ }^{25}$ Luis Ma'luf al-Yusu'i, Al-Munjid fî al-Lughah wa al-A'lam (Beirut: Dâr al-Masyriq. 1988), hlm. 893.

${ }^{26} \mathrm{Abd}$ al-Rahman al-Juzayri, Kitab al-Fiqh 'alâ alMadzâhib al-Arba'ah (Beirut: Dâr al-Fikr. 1996), hlm. 210. Wahbah al-Zuhayly, Al-Figh al-Islâmi wa Adilatuh (Beirut: Dâr al-Fikr. 1983), hlm. 37. kepada pihak lain untuk menjaga hartanya, baik secara sahrih maupun secara dalalah.

Madzhab Mâliki, hampir senada dengan Madzhab Syâfiî̀ mengartikan wadi'ah sebagai perwakilan dalam menjaga harta yang dimiliki atau dihormati secara khusus dengan cara tertentu. Madzhab Hanbali mengartikan wadi'ah dengan prinsip perwakilan dalam penjagaan harta yang bersifat tabarru' atau prinsip penerimaan harta titipan sebagai wakil dalam penjagaannya.

Secara komulatif, wadi'ah memiliki dua pengertian. Pertama, pernyataan dari seseorang yang telah memberikan kuasa atau mewakilkan kepada pihak lain untuk memelihara atau menjaga hartanya. Kedua, sesuatu atau harta yang dititipkan seseorang kepada pihak lain agar dipelihara atau dijaganya. ${ }^{27}$

Keabsahan prinsip wadi'ah ini didasarkan pada Al-Quran surat al-Nisâ ayat 58:

$$
\text { إنّ الله يأمركم ان تؤدّوا الأمانات إلى أهلها }
$$

"Sesungguhnya Allah menyuruh kamu menyampaikan amanat kepada yang berhak menerimanya ......"

Dipertegas pula dalam surat al-Bâqarah ayat 283:

$$
\text { فإن أمن بعضكم فليؤدّ الذى اؤتمن أمانته ولييّق الله ربّه }
$$

"Jika sebagian kamu mempercayai sebagian yang lain, maka hendaklah yang dipercaya itu menunaikan amanatnya dan hendaklah bertaqwa kepada Allah Tuhannya".

Sedangkan Hadits yang dijadikan sebagai dasar dalam mengabsahkan prinsip wadi'ah ini adalah hadits dari Anas RA bahwa Rasulullah SAW bersabda: "Tunaikan amanat kepada orang yang menunaikan amanat kepadamu dan janganlah membalas khianat orang yang telah mengkhianatimu" (Riwayat alTurmudzi dan Abû Dawd).

Wadi'ah sebagai salah satu bentuk prinsip dalam fikih muamalah ternyata paling banyak digunakan dalam lembaga keuangan

\footnotetext{
${ }^{27}$ Lihat, Yadi Janwari, Prinsip Operasional Bank Muamalat Indonesia dalam Operspektif al-Madzâhib alArba'ah. Tesis (Jakarta: Program Pascasarjana IAIN Syarif Hidayatullah. 1998), hlm. 128-129.
} 
Syari'ah, terutama dalam usaha penge-rahan dana dari masyarakat. Bank Islam menggunakan wadi'ah sebagai salah satu prinsip operasional. Mekanisme operasional wadi'ah di Bank Islam ini adalah perjanjian simpan menyimpan atau penitipan barang berharga antara pihak yang mempunyai barang (nasabah) dan pihak yang diberi keepercayaan (bank). Mekanisme operasional wadi'ah ini teraplikasi pula di Baitul Mal wa Tamwil (BMT).

Aplikasi wadi'ah ini lebih kentara lagi pada prinsip operasional dan produk Unit Simpan Pinjam Syari'ah (USPS). Pada lembaga keuangan Syari'ah ini wadi'ah ini dijadikan sebagai prinsip operasional dan produk unggulan. Hal ini seiring dengan tujuan pendiriannya, yakni menghimpun potensi dana yang dimiliki masyarakat melalui simpanan.

\section{Prinsip Murâbahah}

Murâbahah secara bahasa berasal dari lafazh ribh yang berarti ziyâdah (tambahan). Sedangkan pengertian murâbahah secara istilah telah banyak didefinisikan oleh para fuqaha. Misalnya Hanafiyah mengartikan murâbahah dengan menjual sesuatu yang dimiliki senilai harga barang itu dengan tambahan ongkos. Senada dengan pengertian ini dikemukakan pula oleh Mâlikiyyah, yang mengartikan murâbahah dengan menjual barang sesuai harga pembelian disertai dengan tambahan keuntungan yang diketahui oleh penjual dan pembeli. ${ }^{28}$

Prinsip murâbahah ini diaplikasi di beberapa lembaga keuangan syari'ah sebagai salah satu prinsip atau produk dalam usaha penyaluran dana kepada masyarakat. Di Bank Islam murâbahah ini dipahami sebagai mekanisme operasional penjualan suatu barang dengan harga pokok ditambah keuntungan yang disetujui secata bersama antara pihak bank sebagai penjual dengan nasabah sebagai pembeli. Lebih riil, prinsip murâbahah ini di Bank Islam dikedepankan produk Pembiayaan Murâbahah.

Sebagai lembaga keuangan Syari'ah non-perbankan, ternyata Baitul Mal wa Tamwil (BMT) pun menggunakan murâbahah se-

\footnotetext{
${ }^{28}$ Abdurrahmân al-Juzayri, Kitâb al-Fiqh. hlm. 258.
}

bagai salah satu prinsip dan produknya. Makna dan mekanisme murâbahah di BMT tampaknya tidak berbeda dengan makna dan mekanisme pelaksanaan Bank Islam.

\section{Prinsip Al-Bay' bi Tsaman Ajil}

Al-Bay' bi tsaman ajil ini sebenarnya merupakan bagian dari jual beli (bay'). Oleh karena itu, pengertiannya harus berangkat terlebih dahulu dari pengertian jual beli. Terdapat beberapa pengertian jual beli yang telah dikemukakan oleh para fuqaha. Sayyid Sâbiq mengartikan jual beli dengan Penukaran harta dengan harta lain dengan cara saling merelakan atau memindahkan hak milik dengan ada penggantinya dengan yang dizinkan. ${ }^{29}$

Senanda dengan pengertian tersebut, Hasbi Ash-Shiddiqie menyatakan bahwa yang dimaksud dengan jual beli adalah prinsip yang tegak atas dasar penukaran hak milik secara tetap. Dari dua pengertian tersebut, maka dapat dipahami bahwa pada intinya yang dimaksud dengan jual beli adalah prinsip saling menukar harta secara tetap di antara kedua belah pihak dengan memenuhi ketentuan-ketentuan yang dibenarkan syara.$^{30}$

Oleh karena prinsip Al-Bay" bi altsaman ajil merupakan bagian dari prinsip jual beli, maka pengertiannya tidak jauh berbeda dengan jual beli (bay'). Hal yang membedakannya adalah dalam cara pembayarannya: kalau jual beli secara umum dibayar secara kontan, sedangkan dalam al-bai' bi tsaman ajil pembayarannya dilakukan dengan cara tidak tunai atau ditangguhkan (ajil) atau dengan cara dicicil.

Dewasa ini, prinsip Al-Bay' bi al-tsaman ajil tampaknya telah digunakan oleh beberapa lembaga keuangan Syari'ah sebagai prinsip operasional atau produk yang ditawarkan, khususnya oleh Bank Islam dan Baitul Mal wa Tamwil (BMT). Secara operasional, al-bai' bi tsaman ajil di Bank Islam atau BMT diartikan dengan pem-

\footnotetext{
${ }^{29}$ Sayyid Sâbiq, Fikih al-Sunnah (Beirut: Dâr al-Fikr. 1983), hlm. 126.

${ }^{30}$ Hasbi Ash-Shiddieqy, Pengantar Fikih Muamalah (Jakarta: Bulan Bintang. 1984), hlm. 97.
} 
biayaan untuk pembelian barang dengan cicilan. ${ }^{31}$

Syarat-syarat dasar Al-Bay' bi al-tsaman ajil ini hampir sama dengan murâbahah. Perbedaan di antara keduanya terletak pada cara pembayaran, di mana pada murâbahah dilakukan secara tunai setelah terjadi akad. Sedangkan pada Al-Bay' bi tsaman ajil pembayaran dilakukan secara cicilan setelah pembeli memperlihatkan hasil usahanya atau pada saat jatuh tempo yang disepakati.

\section{Prinsip Wakâlah}

Secara bahasa, istilah wakâlah berarti hifzh, kifâyah dan dlamân. ${ }^{32}$ Sedangkan secara istilah, menurut al-Dimyati, wakâlah berarti penyerahan seseorang atas urusannya kepada pihak lain yang di dalamnya terdapat penggantian. ${ }^{33}$ Menurut Hasbi Ash-Shiddieqy, wakâlah berarti prinsip penyerahan kekuasaan, di mana dalam prinsip itu seseorang menunjuk orang lain sebagai gantinya dalam bertindak. ${ }^{34}$ Dari beberapa pengertian itu, maka dapat dipahami bahwa yang dimaksud dengan wakâlah adalah prinsip perwakilan dari seseorang (muwakkil) kepada pihak lain (wâkîl) untuk melakukan perbuatan hukum atas nama muwakil.

Keabsahan wakâlah ini didasarkan pada firman Allah SWT surat al-Kahfi ayat 19:

$$
\text { فابعثوا أحدكم بورقكم هذه إلى المدينة }
$$

“ ..... Maka suruhlah salah seorang di antara kamu pergi ke kota dengan membawa uang perakmu ini .......".

Dipertegas pula dalam surat An-Nisa ayat 35:

$$
\text { وإن خفتم شقاق بينهما فأبعثوا حكما مّن أهلها }
$$

“Maka jika kamu mengkhawatirkan ada perseng-ketaan antara keduanya, maka kirimlah seseorang juru damai dari keluarga laki-laki dan seorang juru damai dari keluarga perempuan".

Selain didasarkan pada kedua ayat itu, keabsahan wakâlah juga diperkuat oleh

\footnotetext{
${ }^{31}$ Yadi Janwari, Prinsip Operasional. hlm. 23.

${ }^{32} \mathrm{Abd}$ al-Rahman al-Juzayri, Kitâb al-Fiqh. hlm. 143.

${ }^{33}$ Sayyid Muhammad Syatha al-Dimyati, l'anah alThâlibin (Semarang: Thaha Putra, t.th.), hlm. 84.

${ }^{34}$ Hasbi Ash-Shiddieqy, Kitab al-Fiqh. hlm. 91.
}

beberapa riwayat yang menje-laskan bahwa Rasulullah SAW pernah melakukan prinsip wakâlah, antara lain riwayat menjelaskan Jâbir RA berkata, "Aku keluar pergi ke Khaibar, lalu aku datang kepada Rasulullah SAW, dan beliau bersabda, 'Bila engkau datang pada wakilku di Khaybar, maka ambillah darinya 15 wasq' (HR Abu Dawud).

Berkenaan dengan aplikasi prinsip wakâlah oleh lembaga keuangan atau ekonomi syari'ah sebagai sebuah prinsip operasional atau produk, hingga saat ini baru tampak di Perbankan Islam, sedangkan di lembaga ekonomi atau keuangan syari'ah lainnya belum tampak. Di Bank Islam, wakâlah dimplementasikan dalam bentuk Letter of Curent $(L / C)$. Dalam hal ini, nasabah bertindak sebagai muwakil sedang bank bertindak sebagai wâkil. Sedangkan perbuatan hukum yang dilakukan bank sebagai wâkil adalah membayar kepada bank koresponden dengan mempergunakan uang nasabah yang didepositokan serta menyerahkan dokumen terkait kepada pihak nasabah.

\section{Prinsip Kafalah}

Kafalah secara bahasa berarti dhaman (jaminan), hamalah (beban), dan za'amah (tanggungan). Sedangkan secara istilah, menurut ulama Ahnaf sebagaimana dikutip Sayyid Sâbiq, kafalah berarti penggabungan tanggungan kâfîl (penanggung) kepada penanggung asal (ashîl) dalam tuntutan dengan jiwa, utang, barang, atau perbuatan. Ulama lain mengartikan kafalah sebagai penggabungan dua tang-gungan dalam tuntutan dan utang. Senada dengan pengertian itu dikemuakan pula oleh Taqi alDin bahwa kafalah berarti penggabungan sebuah tanggungan kepada tanggungan yang lain. ${ }^{35}$ Demikian pula dengan Hasbi Ash-Shiddieqy menyatakan bahwa kafalah adalah menggabungkan dzimah kepada dzimah lain dalam penagihan. ${ }^{36}$

Dari beberapa definisi di atas, maka dapat difahami bahwa prinsip utama dalam kafalah adalah penggabungan di antara

\footnotetext{
${ }^{35}$ Abu Bakr Muhammad al-Taqiyyuddîn, Kifâyah alAkhyâr (Bandung: Al-Ma'arif, t.th.), hlm. 276.

${ }^{36}$ Hasbi Ash-Shiddieqy, Kitab al-Fiqh. hlm. 86.
} 
dua jenis tanggungan, yakni antara kafil dengan ashil. Keabsahan dari prinsip kafalah dalam fikih mu'âmalah pertama-tama didasarkan pada firman Allah SWT dalam surat Yusuf ayat 66 yang berbunyi:

$$
\text { قال لن أرسله معكم حتّى تتوتون موثقا منّ الله لتأتنيّي }
$$

"Ya'kub berkata: "Aku tidak membiarkannya pergi bersamamu sebelum kau memberikan janji yang teguh atas nama Allah bahwa kamu pasti memba-wanya kembali kepadaku".

Legitimasi prinsip kafalah ini dipertegas oleh surat Yûsuf ayat 72:

$$
\text { ولمن جاء به حمل بعير وّانا به زعيم }
$$

"Dan barangsiapa yang dapat mengembalikannya piala raja, maka ia akan memperoleh bahan makanan seberat beban unta dan aku yang menjamin terhadapnya".

Sedangkan dalam Hadits ditemukan dalam riwayat Abu Dawud bahwa Rasulullah SAW bersabda: "Pinjaman hendaklah dikembalikan dan yang menjamin hendaklah membayar". Hadits tersebut memperkuat ketentuan ayat di atas tentang kebolehan melakukan transaksi dengan menggunakan prinsip kafalah.

Berkenaan dengan aplikasi kafalah ini, sebagaimana wakâlah, hingga saat ini baru ditemukan di Bank Islam. Di dalam Bank Islam, kafalah diimplementasikan dalam bentuk Letter of Guarantee ( $L / G)$. Fasilitas $L / G$ ini disebut pula dengan Bank Garansi, di mana bank memberikan jaminan atas nasabahnya atas pembayaran utang atau jaminan prestasi. ${ }^{37}$

\section{Prinsip Qardl}

Qardl berarti harta yang diberikan muqaridl (pemberi pinjaman) kepada muqtaridh (penerima pinjaman) untuk dikembalikan semisalnya sesuai ukurannya..$^{38}$ Dengan kata lain, qardl ini berarti pinjam meminjam

\footnotetext{
${ }^{37}$ Untuk lebih jelasnya mengenai mekanisme Letter of Guarantee di Bank Islam ini, lihat Karnaen Perwataatmadja dan Muhammad Syafi'i Antonio, Apa dan Bagaimana Bank Islam (Yogyakarta: Dana Bhakti Wakaf. 1992), hlm. 37-38.

${ }^{38}$ Sayyid Sâbiq, Fikih al-Sunnah. hlm. 182.
}

barang (dalam pengertian luas, termasuk mata uang) yang harus dikembalikan sesuai nilai dari barang yang dipinjam itu.

Keabsahan prinsip qardl ini, dalam syarî'at Islam didasarkan pada Al-Quran surat al-Bâqarah ayat 245 yang berbunyi:

$$
\text { كثيراة ذا الّذي يقرض الله قرضا حسنا فيضاعفه له اضعافا }
$$

"Siapakah yang mau memberi pinjaman kepada Allah pinjaman yang baik, maka Allah akan melipatgandakan pembayaran kepadanya dengan lipat ganda yang banyak".

Selain itu, keabsahan qardl ini didasarkan pada Hadits Nabi SAW yang diterima dari Anas RA dan diriwayatkan Ibn Majah bahwa Rasulullah SAW telah bersabda: "Apabila salah seorang di antara kamu mengutangkan sesuatu kemudian diberi hadiah atau dinaikan di atas kendaraannya, maka hendaklah jangan diterimanya hadiah itu dan janganlah ia naik kendaraan itu kecuali jika memang antara keduanya berlaku demikian sebelum terjadi utang piutang".

Dewasa ini, prinsip qardl telah diaplikasikan pada beberapa lembaga keuangan syari'ah, khususnya di Bank Islam dan Baitul Mal wa Tamwil (BMT). Implementasi prinsip qardl, di kedua lembaga keuangan syari'ah tersebut memiliki pemaknaan yang hampir sama. Bahkan dengan menggunakan istilah operasional yang sama pula, yakni al-qardl alhasan.

Kerangka operasional prinsip al-qardl alhasan pada Bank Islam dan BMT itu mengandung arti bahwa bank atau BMT memberikan pinjaman lunak kepada nasabah yang membutuhkan dana, khususnya untuk kebutuhankebutuhan yang sifatnya konsumtif. Prinsip ini sama dengan pinjaman lunak di lembaga keuangan keuangan konvensional.

Berbeda dengan praktek lembaga keuangan konven-sional, prinsip al-qardl al-hasan di lembaga keuangan syari'ah tidak dikenakan suku bunga. Dalam pengertian, kewajiban nasabah hanya mengembalikan sejumlah uang yang telah dipinjamnya. Kalaupun ada beban yang mesti ditanggung oleh nasabah, hanyalah beban biaya untuk pengurusan admi-nistrasi saja. 


\section{E. Proses Legislasi UU No. 10 Tahun 1998 tentang Perbankan}

Dalam tulisan ini, penulis ingin menggambarkan secara ringkas proses legislasi UU No. 10 Tahun 1998 tentang Perbankan. Merujuk kepada bagian awal pembahasan ini tentang dasar pembentukannya, proses legislasi UU No. 10 Tahun 1998 tentang Perbankan dilakukan melalui 4 (empat) tahapan:

1. Tahap I: Penyusunan dan Penyempurnaan Draft Awal

Seperti proses legislasi UU pada umumnya, proses legislasi UU No. 10 Tahun 1998 tentang Perbankan juga diawali dengan penyusunan naskah awal berupa naskah akademik (academic draft). Istilah ini banyak dikenal dalam ilmu perundang-undangan (alilm Taqnîn al-ahkam). Tahapan ini mencakup:

a. Pemerintah, DPR, organisasi sosial dan kemasyarakatan (LSM) serta elemenelemen yang terkait, mengangkat wacana-wacana perlunya dilakukan amandemen terhadap UU No. 7 Tahun 1992 tentang Perbankan. Melalui forum-forum ilmiah tentang bank syari'ah, seperti seminar, simposium, lokakarya, workshop, dan sebagainya. Sosialisasi gagasan perubahan regulasi bank syari'ah juga dilakukan melalui media cetak dan media elektronik.

b. Pemerintah, DPR, organisasi sosial dan kemasyarakatan (LSM) serta elemenelemen terkait, masing-masing menyusun Draft Awal UU Perbankan Perubahan dari UU No. 7 Tahun 1992. Draft Awal Draft Awal UU Perbankan Perubahan tersebut selanjutnya dibahas kembali pada forum-forum ilmiah secara formal dan informal. Beberapa rekomendasi sebagai hasil dari pertemuanpertemuan ilmiah itulah kemudian menjadi masukan berharga bagi penyempurnaan Naskah Draft Awal UU Perbankan Perubahan.

c. Pembentukan Tim Independen yang berfungsi membahas, mengkaji dan menelaah seluruh point yang terdapat dalam Draft RUU Perbankan Perubahan itu - untuk selanjutkan diperbaiki dan disempurnakan menurut kepatutan hukum dan tata aturan penyusunan pera- turan dan perundang-undangan di Indonesia.

\section{Tahap II: Penyempurnaan dan Penga- juan Draft RUU}

Pada tahap kedua, proses penyusunan Draft RUU Perbankan Perubahan yang sudah diperbaiki dan dilengkapi dengan saran dan rekomendasi dari banyak pihak, selanjutnya diajukan kepada Presiden untuk dikaji dan dipertimbangkan lebih jauh. Pada tahapan ini, pemerintah (dalam hal ini Presiden) melakukan sejumlah langkah-langkah teknis sebagai berikut:

a. Presiden membentuk Tim Ahli yang terdiri dari staf ahli kepresidenan, Departemen Hukum dan HAM, pakar ilmu ekonomi dan praktisi ekonomi, serta komponen masyarakat yang dianggap layak diikutsertakan dalam proses pembahasan Draft RUU Perbankan Perubahan.

b. Pembahasan Draft RUU Perbankan Perubahan pada tingkat Tim Ahli pemerintahan, yang selanjutnya pemerintah melakukan Rapat Koordinasi dengan DPR untuk menindaklanjuti pembentukan Draft RUU Perbankan Perubahan pada tingkat yang lebih teknis dan rinci.

c. Setelah diperoleh kesepakatan antara pemerintah dan DPR, kemudian Presiden mengajukan Draft RUU Perbankan Perubahan itu kepada DPR untuk dikaji lebih dalam sehingga dapat ditetapkan sebagai Undang-Undang.

\section{Tahap III: Pembahasan dan Pengesahan UU}

Tahapan selanjutnya, kewenangan menyusun dan mengesahkan UU berada di tangan DPR. Dalam hal ini, DPR melakukan pembahasan Draft RUU Perbankan Perubahan dengan mempertimbangkan beberapa faktor, yakni:

a. Kepatutan menurut prinsip dan azas hukum, di mana Draft RUU Perbankan Perubahan mesti dilandasi norma-norma filosofis, sosiologis, politis dan yuridis, serta tidak bertentangan dengan ketentuan hukum yang lebih tinggi, sehingga 
dapat menjamin keadilan dan kepastian hukum;

b. Keterwakilan, maksudnya adalah mempertimbangkan masukan/rekomendasi dari semua komponen masyarakat dalam proses pengambilan keputusan;

c. Tujuan pembentukan Draft RUU Perbankan Perubahan tidak semata-mata memper-timbangan tuntutan dan dukungan dari masyarakat, tetapi harus mampu menjamin kepastian hukum bagi pengembangan bank syari'ah di Indonesia.

Oleh karena itu, sebelum disahkan menjadi UU, DPR melakukan beberapa langkah teknis dan strategi, antara lain:

a. DPR melakukan rapat dengar pendapat (public hearing) dengan elemen sosial politik yang berkepentingan dengan proses pembentukan Draft RUU Perbankan Perubahan. Beberapa pertemuan pernah digelar oleh DPR dengan para ahli ekonomi, praktisi ekonomi, dan beberapa LSM yang concern di bidang perbankan syari'ah.

b. DPR juga melakukan rapat dengar pendapat (public hearing) dengan pemerintah yang dalam hal ini adalah Menteri Hukum dan HAM (Departemen Hukum dan HAM), Mahkamah Agung, Menteri Perekonomian, Menteri Keuangan, Direktur BI, Majelis Ulama Indonesia (MUI) dan Asosiasi Pengusaha Perbankan Indonesia (APPI).

c. DPR membentuk suatu Panitia Kerja (Panja) atau Panitia Khusus (Pansus) melalui suatu Sidang Komisi yakni Sidang Komisi IV DPR RI.

d. DPR menggelar sidang paripurna untuk mendengarkan pandangan fraksi-fraksi. Pandangan fraksi-fraksi cenderung beragam ada menyetujui tanpa catatan dan ada pula yang menyetujui dengan catatan.

e. Dalam sidang paripurna tersebut, hampir semua fraksi menyetujui disahkannya Draft RUU Perbankan Perubahan. Selanjutnya, pimpinan DPR mengambil suatu keputusan berdasarkan persetujuan fraksi-fraksi dan menyamaikan panda- ngan kepada ihak pemerintah (Presiden).

f. Setelah DPR menyetujui Draft RUU Perbankan Perubahan, selajutnya pemerintah dalam hal ini Presiden mengesahkan UU No. 10 Tahun 1998 tentang Perbankan sebagai perubahan dari UU No. 7 Tahun 1992.

g. UU Perbankan Perubahan disahkan di Jakarta pada tanggal 10 November 1998 oleh Presiden Republik Indonesia yakni Bacharuddin Jusuf Habibie dan ditandatangani pula oleh Menteri Negara/Sekretaris Negara Republik Indonesia yakni Akbar Tandjung serta dituangkan dalam Lembaran Negara Reublik Indonesia Tahun 1998 Nomor 182.

Mengutip pendapat Prof. Dr. Rachmat Syafe'i, A $^{39}$ dalam tulisannya di HU Pikiran Rakyat dijelaskan bahawa terlepas dari lahirnya UU No. 10 Tahun 1998 tentang Perbankan, hal yang harus mendapat perhatian pula adalah dari sisi sumber daya manusia yang diserap oleh bank-bank syariah yang kenyataannya adalah sarjana-sarjana ekonomi yang "belajar" ekonomi Islam dalam beberapa bulan bahkan minggu lewat kursuskursus itu, sementara sarjana syariah jurusan mu'amalah belajar ekonomi Islam itu bertahun-tahun. Dari sisi kompetensi tentu saja para sarjana syariah perlu dipertimbangkan sebagai upaya untuk menumbuhkan kepercayaan dan keyakinan masyarakat.

Di samping itu, beberapa hal yang perlu segera disempurnakan dalam upaya menjadikan bank syariah sebagai perbankan yang mendapat kepercayaan dan keyakinan masyarakat serta terpisah dari bank konvensional antara lain mengenai:

a. Ketentuan-ketentuan yang mengatur mengenai prinsip kehati-hatian;

b. Standar akuntansi, audit dan pelaporan;

c. Instrumen yang diperlukan untuk pengelolaan likuiditas;

d. Instrumen moneter yang sesuai dengan prinsip syariah untuk keperluan pelaksa-

\footnotetext{
${ }^{39}$ Rachmat Syafe'i, Tinjauan Yuridis Terhadap Perbankan Syari'ah dalam HU Pikiran Rakyat edisi 21 Maret 2005 dan lihat pula dalam http://www.pikiranrakyat.com/cetak/2005/0305/21/0802.htm, diakses tanggal 20 Februari 2014.
} 
naan tugas bank sentral, dan lain sebagainya;

e. Memberikan kepercayaan kepada perguruan tinggi negeri yang berkompetensi syari'ah, UIN dan IAIN misalnya.

Hal-hal tersebut di atas sangat diperlukan agar bank syariah dapat menjadi elemen dari sistem moneter yang dapat menjalankan fungsinya secara baik dan mampu berkembang serta bersaing dengan bank konvensional. Selain itu, dari sisi kelembagaan dan landasan hukum penyelenggaraan perbankan syariah pun perlu mendapatkan penyempurnaan. Hal ini sebagai upaya antisipasi terhadap berbagai permasalahan yang mungkin timbul dalam operasionalisasi bank syariah di lapangan. Misalnya terjadi penyimpangan-penyimpangan antara lain, sengketa, penipuan, pencucian uang dan sebagainya.

Walaupun pada hakikatnya bank syariah didirikan atas dasar moralitas dan unsur agama, penyimpangan ini mungkin akan terjadi sehingga dibutuhkan perangkat hukum baik dari sisi kelembagaan atau dari sisi undang-undang itu sendiri yang lebih jelas dan tegas dalam mengatur permasalahan ini. Dan untuk melengkapi kepentingan di atas, maka dari sisi materi undang-undang, maka sangat perlu juga mendorong lahirnya "Kompilasi Hukum Ekonomi Islam" dalam rangka mempersiapkan undang-undang yang lebih tinggi di samping undang-undang bank syariah yang sedang digodok di Mahkamah Agung akhir-akhir ini.

Kompilasi Hukum Muamalat dan undang-undang lainnya, harus semata-mata ditunjukkan sebagai hal yang bukan tidak mungkin dan malah harus dilihat sebagai implementasi dari adanya jaminan serta tidak adanya pertentangan dengan hukum positif perdata yang kita anut sebagaimana dinyatakan dalam Pasal 1338 yang menganut "asas kebebasan berkontrak", dan ini berarti bahwa setiap individu dari setiap anggota masyarakat bebas melakukan ikatan dan perjanjian sesuai kehendak, sepanjang tidak bertentangan dengan kepentingan masyarakat yang lebih banyak. Bahkan pasal tersebut menjamin pula bahwa, "perjanjian itu berlaku sebagai undang-undang" yang mengikat bagi mereka yang membuat dan menyepakatinya. (al-'aqd syari'at al-muta'aqidain).

\section{F. Penutup}

Setelah dilegislasikan UU No. 10 Tahun 1998 tentang Perbankan, kemajuan lembaga perbankan syari'ah di Indonesia relatif berkembang pesat, karena kendala-kendala institusional maupun yuridis telah diatasi. Menurut hemat penulis, prinsip bagi hasil (profit and loss-sharing) sejenis mudlârabah sangat cocok diterapkan pada sektor riil dan pengembangan usaha kerakyatan, karena sebenarnya sudah sangat seusai dengan pola yang diharapkan mampu me-back up industri besar yang kini mengalami tingkat persaingan yang sangat kompetitif.

Bagi hasil mudlârabah di bank syariah bisa dioptimalisasikan melalui berbagai langkah, antara lain adalah kesinambungan dan transparansi informasi terhadap usaha yang akan dijalankan. Informasi usaha dan pasar adalah sesuatu yang sangat penting dan berharga dalam setiap usaha. Oleh karena itu langkah ini bisa dimaksimalkan melalui database yang aktual, rinci, dan faktual, sambil terus mencari dan menemukan format usaha yang sesuai dengan iklim usaha tersebut.

Langkah lainnya adalah dengan pengembangan industri-industri kecil yang dibina langsung oleh bank syariah. Industri ini benar-benar milik rakyat, prospektif, dan dikelola dengan amanah. Industrialisasi adalah salah satu kunci penting bagi negara kita untuk dapat survive di saat krisis seperti ini, dan melatih bangsa kita menjadi bangsa yang mandiri.

Langkah terakhir yang perlu segera ditindaklakjuti adalah membuat aturan dan regulasi yang tepat, terstandarisasi dan sesuai dengan prinsip syariah. Umat Islam sangat berharap legalisasi produk bank syari'ah bisa dipertimbangkan oleh DPR dan pemerintah untuk menjadi hukum yang positif. Aturan ini nantinya menjadi payung yang sah terhadap gerak-gerik pelaksanaan pembiayaan mudlârabah terhadap industri-industri kecil.

Mudah-mudahan semakin banyak pihak yang memahami pentingnya prinsip bagi hasil (profit and loss-sharing) dalam memain- 
kan peranannya pada setiap pembiayaan usaha di Bank Syariah. Jika ini berhasil dilakukan, maka sektor riil dapat berkembang pesat dan negara kita akan memiliki industri usaha yang kuat. Pada akhirnya, ini diharapkan dapat mengatasi berbagai permasalahan ekonomi yang kini melanda di negara kita, karena sesungguhnya prinsip bagi hasil (profit and loss-sharing) adalah pola yang tepat dalam pengembangan sektor riil di negara kita.

\section{Daftar Pustaka}

Antonio, Muhammad Syafi'i. 2001. Bank Syariah dari Teori ke Praktik. Jakarta: Gema Insani Press.

Ash-Shiddieqy, Hasbi. 1984. Pengantar Fikih Muamalah. Jakarta: Bulan Bintang.

Dimyati, Sayyid Muhammad Syatha, al. t.th. l'ânah al-Thâlibîn. Semarang: Thaha Putra.

Eskarni Fushali. Ekonomi Islam Solusi Tepat untuk Kemaslahatan Umat. Lihat dalam http://www.majalahsinar.com/index.php ?option=com_content\&task=view\&id=9 2\&ltemid=7, diakses tanggal 13 Februari 2014.

Ibn Qudamah, Al-Mughni. 1981. Beirut: Dâr alFikr.

Janwari, Yadi. 1998. Prinsip Operasional Bank Muamalat Indonesia dalam Operspektif al-Madzâhib al-Arba'ah. Tesis. Jakarta: Program Pascasarjana IAIN Syarif Hidayatullah.

- 2000. Lembaga-Lembaga Perekonomian Syari'ah. Bandung: Pustaka Mulia dan Fakultas Syari'ah IAIN Sunan Gunung Djati.

Juzayri, Abdurrahmân, al-. 1996. Kitab al-Fiqh 'alâ al-Madzâhib al-Arba'ah. Beirut: Dâr al-Fikr.
Konsideran Undang-Undang Nomor 10 Tahun 1998 tentang Perbankan.

Nur Fakhrus Salis. Penerapan dan Pengembangan Prinsip Syari'ah di Lembaga Keuangan Syari'ah, kutipan dari makalah Nur Fakhrus Salis, mahasiswa Jurusan Perbankan Syari'ah di STAIN Pekalongan.

Perwataatmadja, Karnaen dkk. 1992. Apa dan Bagaimana Bank Islam. Yogyakarta: Dana Bhakti Wakaf.

Rachmat Syafe'i. Tinjauan Yuridis Terhadap Perbankan Syari'ah. Dalam HU Pikiran Rakyat edisi 21 Maret 2005 dan lihat pula dalam http://www.pikiran-rakyat.com/cetak/2005/0305/21/0802.htm, diakses tanggal 20 Februari 2014.

Rahman, Afzalur. 1996. Doktrin Ekonomi Islam. Yogyakarta: Dana Bhakti Wakaf.

Sâbiq, Sayyid. 1984. Fiqh al-Sunnah. Beirut: Dar al-Fikr.

Saeed, Abdullah. 1996. Islamic Banking and Interest: A Study of the Prohibition of Riba and its Contemporary Interpretation. Leiden: EJ Brill.

Taqiyyuddîn, Abu Bakr Muhammad, al-. t.th. Kifâyah al-Akhyâr. Bandung: Al-Ma'arif.

Tri Hartanto. Sebuah Keharusan Undang-undang Khusus Bank Syari'ah. Lihat penjelasan lengkapnya dalam http://www.hukumonline.com/detail.asp?id=9235 \&cl=Berita, diakses tanggal 13 Februari 2014.

Yusu'i, Luis Ma'luf, al-. 1988. Al-Munjid fî alLughah wa al-A'lâm. Beirut: Dar alMasyriq.

Zuhayly, Wahbah. 1984. Al-Fiqh al-Islâmi wa Adilatuh. Beirut: Dâr al-'Ilm. 